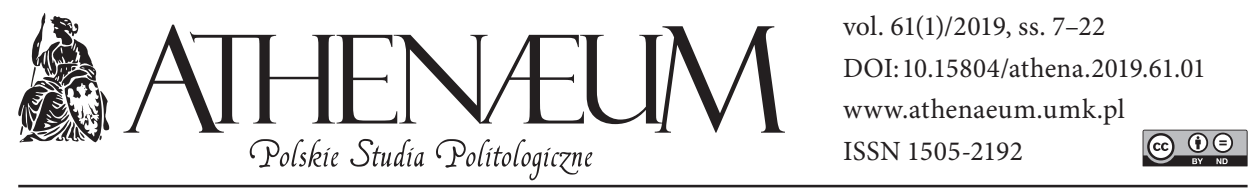

\title{
PROCES DEMOKRATYZACJI TUNEZJI W ŚWIETLE TEORII TRANSFORMACJI SYSTEMOWEJ
}

\author{
TUNISIA'S DEMOCRATISATION PROCESS IN THE LIGHT \\ OF THE SYSTEM TRANSITION THEORIES
}

Ewa Szczepankiewicz-Rudzka* ๑)

\begin{abstract}
ABSTRAKT
Tunezja jako jedyne państwo obszaru Afryki Północnej i Bliskiego Wschodu obrała drogę transformacji demokratycznej w następstwie wydarzeń rewolucyjnych tzw. arabskiej wiosny. W świetle dominujących w naukach o polityce teorii transformacji proces „przejścia demokratycznego" odbywa się w dwóch fazach. W pierwszej z nich dochodzi do obalenia autorytarnego reżimu i ustanowienia demokracji, w drugiej kolejności następuje jej konsolidacja. Jednym z czynników dominujących, ułatwiających ustanowienie demokracji, jest konsensualna postawa elit politycznych. Celem artykułu jest próba uchwycenia zjawiska budowy demokracji tunezyjskiej w świetle powyższych stadiów. W dalszej kolejności wykazane zostanie, że zasadniczą przesłanką ułatwiającą transformację demokratyczną i zarazem modelem, w którym dokonuje się zmiana, jest konsens polityczny w procesie ustanawiania instytucji i prawa Tunezji.
\end{abstract}

Słowa kluczowe: Tunezja; transformacja demokratyczna; konsens
Tunisia is the only country of the Middle East and North Africa Region which has chosen the democratic transformation to follow the Arab Spring uprisings. Under the prevailing transitology theories, the democratization proceeds in two major phases. The first one leads to the overthrow of the authoritarian regime and "installation of a democratic government", while the second one consists of the consolidation of democracy. One of the dominant factors which facilitate the establishment of democracy is the consensual attitude of the political elites. The paper aims to study the phenomenon of the above mentioned stages of Tunisian democratization process. Subsequently, the author attempts to prove that the political consensus of the elites is at the same time a driving force and serves as a model for democratic change to be made.

Keywords: Tunisia; democratic transformation; consensus

* Uniwersytet Jagielloński w Krakowie, Wydział Studiów Międzynarodowych i Politycznych. 


\section{ROZWAŻANIA WSTĘPNE}

Fala rewolucji, która, począwszy od 2011 r., doprowadziła do obalenia wieloletnich autorytarnych reżimów w Afryce Północnej i na Bliskim Wschodzie, otworzyła również pole dla badań z zakresu teorii transformacji systemowej, tzw. tranzytologii. Sekwencja „zrywów rewolucyjnych” w Tunezji, Egipcie, Libii, Jemenie czy Syrii okrzyknięta mianem „arabskiej wiosny” przywodzi na myśl wydarzenia rewolucyjne XIX-wiecznej Europy, które do historii przeszły pod nazwą Wiosny Ludów. Zbieżność nazw dowodzi faktu poszukiwania analogii w wydarzeniach $\mathrm{z}$ połowy XIX w. i tych sprzed kilku lat. Pojawiające się zaś w literaturze przedmiotu określenia, takie jak „efekt domina” (Bonnefoy, 2011) czy „fala tunisami” (Potocki, Piskorski, Hładkiewicz, 2014), nawiązują do teorii fal demokratyzacji Samuela Huntingtona (Huntington, 1995).

Z perspektywy siedmiu lat od pamiętnej „rewolucji jaśminowej” w Tunezji, otwierającej przeobrażenia polityczne $\mathrm{w}$ regionie, poszukiwanie paraleli między liberalnym zrywem ubiegłowiecznej Europy czy interpretacje politologiczne rozciągające demokratyzację państw Ameryki Łacińskiej i Europy Środkowo-Wschodniej lat 80. na świat arabski są zbyt daleko idące. Rzeczywistość społeczno-polityczna państw arabskich dotkniętych rewolucyjnym zrywem przedstawia się ponuro. W Egipcie na powrót umocniła się dyktatura militarna, zaś obalenie autokratów w Jemenie i Libii czy takowa próba w przypadku Syrii pogrążyły społeczeństwa w długoletniej wojnie domowej. Z drugiej zaś strony niewielka Tunezja obrała drogę demokratyzacji systemu, stanowiąc wyjątek wśród państw regionu.

Rozważania podjęte $\mathrm{w}$ artykule oparto na hipotezie, iż procesy polityczne, jakie mają miejsce w Tunezji, wpisują się w paradygmat demokratyzacji, a dwa jej podstawowe etapy: tzw. etap przejściowy i konsolidacji, dają się wyraźnie wyodrębnić w przypadku analizowanego państwa. Pozostawiając na marginesie analizę „wyjątku tunezyjskiego” pod kątem czynników determinujących upadek reżimu niedemokratycznego i konsolidujących proces przemiany demokratycznej, główna oś wywodu opiera się na wskazaniu wydarzeń i decyzji politycznych, które stanowią cezurę dla otwarcia okresów „przejścia demokratycznego”, oraz na analizie modelu, w jakim ono się dokonuje.

Dla realizacji określonej problematyki wykorzystano wiodące metody badawcze spośród stosowanych w naukach o polityce. Punkt wyjścia stanowiła metoda empiryczna pozwalająca na zgromadzenie danych oraz informacji dotyczących przebiegu, wyniku i struktury rywalizacji politycznej w Tunezji w okresie 2011-2015. Metoda systemowa znalazła zastosowanie przy poszukiwaniu korela- 
cji między opisywanymi zjawiskami politycznymi. Natomiast metoda jakościowa została wykorzystana do oceny oraz wyjaśniania opisywanych wydarzeń.

\section{PARADYGMATY W TEORIACH TRANSFORMACII DEMOKRATYCZNYCH}

Studia z zakresu tranzytologii stanowią jedną z dziedzin nauk o polityce, której rozwój datuje się na lata $70 . \mathrm{XX}$ w. Pole zainteresowania dyscypliny badawczej stanowią zmiany polityczne, mające miejsce w okresie, którego cezurę z jednej strony wyznacza upadek reżimu autokratycznego, z drugiej zaś moment ugruntowania się demokracji. Podwaliny pod współczesny paradygmat tranzytologii stworzył Dankwart Rustow. W artykule Transitions to Democracy: Toward a Dynamic Model prowadzi do ważkich konkluzji, zwracając uwagę na odrębność procesów przejścia (od dyktatury do demokracji) i tych prowadzących do utrwalenia systemu demokratycznego (Rustow, 1970). Tym samym dyscyplina może być rozpatrywana w kategorii tranzycji (przejścia, jako stadium początkowego) i konsolidacji (Antoszewski, 2011). Co więcej, autor oddzielił myślenie o demokratyzacji jako procesie warunkowanym rozwojem społecznym i gospodarczym. Zwrócił szczególną uwagę na poziom i charakter interakcji między aktorami procesów politycznych. Forma, w jakiej dokonuje się zmiana polityczna i utrwalenie demokratycznych reguł gry, jest funkcją proporcji sił między zwolennikami i przeciwnikami demokracji (Antoszewski, 2011).

W podobnym nurcie badawczym procesów transformacji pozostają G. O'Donnell, P. Schmitter, L. Whitehead, autorzy jednej z najważniejszych prac w dziedzinie tranzytologii: Transitions from Authoritarian Rule. Prospects for Democracy (O'Donnell, Schmitter, Whitehead, 1986).

Tranzycja, w definicji autorów, oznacza wycinek czasu, stanowiący przerwę, tzw. przejście między jednym reżimem a drugim. Okres ten jest stadium pośrednim, który charakteryzuje się konfliktem wokół norm i procedur politycznych. Cechą znamienną tranzycji jest wysoki poziom niepewności reguł, które zostaną ustanowione przez aktorów biorących udział w procesie oraz - co się z tym wiąże - formy, jaką przybierze nowy reżim (O’Donnell, Schmitter, Whitehead, 1986). Natura i kierunki przeobrażeń zależą w pierwszej linii od strategii politycznych przyjętych przez różne grupy uczestników procesu transformacji. Stosunek sił między nimi i stopień konsensualnego nastawienia elit politycznych jest wyznacznikiem kierunku zmian, który obierze proces przekształceń systemu. 
Tranzycja stanowi punkt wyjścia dla kolejnej fazy zmiany demokratycznej konsolidacji. Autorzy zauważają, że zgoda co do stosowania pewnych reguł gry nie świadczy o zakotwiczeniu demokracji samej w sobie, gdyż konsens co do tych reguł może być ograniczony w czasie. Wypracowane w drodze konsensu zasady powinny ulec ugruntowaniu, tzw. konsolidacji, tak by stały się jedynymi obowiązującymi regułami gry (the only game in town; Guilhott, Schmiter, 2000). Innymi słowy, wynegocjowane porozumienie polityczne nie wystarcza, by uznać proces za zakończony. Proces demokratyzacji pozostaje płynny i niepewny, dopóty normy i wartości, których dotyczył konsens, zostaną uznane za obowiązujące i jedyne. Uznanie norm i wartości nie odnosi się tylko i wyłącznie do sfery świadomości, ale obejmuje również stopień ich przyswojenia (Guilhott, Schmiter, 2000).

Podążając tym tropem wywodu, osiągnięcie etapu konsolidacji demokracji nie jest tożsame z momentem wypracowania konsensu, lecz jest efektem wynikającym z istnienia i funkcjonowania instytucji i reguł w dłuższym okresie czasu. Dla uchwycenia idei istnienia i funkcjonowania nowych zasad przywoływany został termin „habituacja” (Rustow, 1970) czy „asymilacja” (Whitehead, 1989), pojęcia oznaczające poziom ich przyswojenia.

Schmitter i Guilhot wskazują, iż procesy tranzycji i konsolidacji nie mogą być ustanowione na jednej osi i rozpatrywane jako kontinuum, gdyż pozostają względem siebie w opozycji. Na etapie tranzycji, gdy demokratyzacja jest $\mathrm{w}$ trakcie ustanawiania, aktorzy uczestniczący w procesie podejmują decyzje niekiedy w pośpiechu. Działaniom tym towarzyszy duża doza niepewności i nieprzewidywalności. W konsolidacji natomiast tranzytolodzy przenoszą ciężar rozważań z człowieka - aktora gry politycznej, wchodzącego w różne interakcje z innymi uczestnikami procesu - na struktury i instytucje, w których schematy działań są stabilne i przewidywalne. Procesy demokratyzacji charakteryzuje więc swoista dychotomia; z jednej strony mamy do czynienia $\mathrm{z}$ teorią zmiany - tranzycją, z drugiej z teorią porządku - konsolidacją. Parafrazując słowa autorów, w fazie pierwszej „aktorzy tworzą instytucje”, realizują strategie, zmienne w zależności od układu sił i celu działań politycznych, w fazie konsolidacji zaś to „instytucje tworzą człowieka” - aktorzy działają w zgodzie z wypracowanymi wcześniej procedurami, najczęściej podświadomie (Whitehead, 1989).

W świetle powyższych rozważań zasadne jest postawienie pytania: jak zmierzyć stopień konsolidacji demokracji, tak by można z całą pewnością stwierdzić wystarczający jej poziom zasymilowania w społeczeństwie? 
Analizę krytyczną dotychczasowych teorii przeprowadził choćby A. Schedler, wskazując problemy w ich zastosowaniu empirycznym (Schedler, 1997a, 1997b). O ile analizy procesów politycznych zachodzące w poszczególnych państwach często odnoszą się do postępów na drodze stabilnej demokracji, o tyle kryteria, jakimi się je mierzy, pozostają dyskusyjne. Identyfikacja rezultatów konsolidacji lub stwierdzenie konsolidacji jako rezultatu udanej transformacji jest niezwykle trudne ze względu na brak wskazania mierników takowej. Definicje zawierają często czynniki normatywne, których łączne spełnienie wyznacza poziom demokracji stabilnej, skonsolidowanej (pluralizm sceny politycznej, wolne wybory, trójpodział władz). Głosy krytyczne dotyczą też sposobu definiowania aktorów, których działania brane są pod uwagę przy ocenie stopnia skonsolidowania systemu. W teorii klasycznej uznaje się ustrój skonsolidowany wówczas, gdy znaczący, kluczowi aktorzy „działają” zgodnie z przyjętymi regułami w długiej perspektywie (Valenzuela, 1992). Zastanawiające w takim ujęciu jest nie tylko ustalenie ram czasowych tej perspektywy, ale także wskazanie podmiotów, których działania brane są pod uwagę. Ich definiowanie pozostaje w gestii oceniającego i co do zasady nie ma charakteru inkluzyjnego. Uwzględnia się przedstawicieli partii politycznych, zaś rola ruchów społecznych, ugrupowań lokalnych i regionalnych tylko w niewielkim stopniu podlega analizie przy ocenie procesów politycznych (Valenzuela,1992).

W dyskursie nad procesami transformacji demokratycznej niezmiernie ważne pozostają teorie Samuela P. Huntingtona, który proponuje badać demokratyzację nie jako odizolowany proces mający miejsce w jednym państwie, ale jako sekwencję zdarzeń dziejących się w kilku państwach. W książce pt. Trzecia fala demokratyzacji Huntington analizuje serię przekształceń z systemów niedemokratycznych do demokracji (Huntington, 1995). Przemiany te mają miejsce w określonym czasie, wśród państw przynależących geograficznie do jednego regionu, które są na tyle liczne, że przeważają nad trendami opozycyjnymi. Wraz z trendem liberalizacji systemów mogą zaistnieć zatem tendencje opozycyjne, takie jak autorytaryzm czy dyktatura.

S.P. Huntington wskazuje, iż dotychczas wystąpiły trzy fale demokratyzacji. Pierwsza objęła lata 1828-1926, druga - 1943-1962, trzecia zaś trwa od 1974 po dzień dzisiejszy. Fale odwrotu rozpoczętych zmian systemowych i powrót do instytucji niedemokratycznych wystąpiły w latach 1922-1942 (pierwsza fala odwrotu) i 1958-1975 (druga fala odwrotu). Trzecia fala demokratyzacji rozpoczęła się - zdaniem Huntingtona - w 1974 r. wraz z początkiem „rewolucji goździków” w Portugalii i trwa do dziś (Huntington, 1995). Huntington, wska- 
zując na kilka przyczyn, które wywołały trzecią falę demokratyzacji, wymienia: (1) jedną przyczynę, (2) rozwój równoległy, (3) efekt lawiny, (4) powszechnie uznawane panaceum (Huntington, 1995).

Teoria fal S.P. Huntingtona jest najbardziej rozpowszechniona, nie jest on jednak jedynym autorem, który wskazywał na cykliczność procesów demokratyzacji. Również Charles Kurzman (Kurzman, 1998), John Markoff, (Markoff, 2015), Larry Diamond (Diamond, 1997) analizują zjawiska demokratyzacji jako równoległe przemiany przebiegające w kilku państwach przynależących do jednego regionu, doszukując się elementów wspólnych przeobrażeń systemowych. Co więcej, nie wszyscy teoretycy procesów transformacji w nurcie badań zapoczątkowanych przez Huntingtona lokują czwartą falę demokratyzacji w Europie ${ }^{1}$. Larry Diamond włącza do czwartej fali grupę państw z Afryki Północnej i Półwyspu Arabskiego, takich jak: Irak, Libia, Syria (Diamond, 1999). Nie brakuje też opracowań politologicznych, rozciągających teorie fal na państwa ogarnięte zrywem arabskiej wiosny (El Husseini, 2011).

\section{POLE ZASTOSOWANIA TEORII TRANSFORMACJI W PRZYPADKU TUNEZJI}

Analiza transformacji w regionie Bliskiego Wschodu i Afryki Północnej w świetle teorii fal jest zabiegiem kontrowersyjnym, mając choćby na uwadze fakt, że obecnie jedynym państwem w regionie doświadczającym demokratyzacji jest Tunezja. Niemniej jednak, w sekwencji wydarzeń rewolucyjnych początku 2011 r., w większości państw MENA można wyodrębnić punkty wspólne, które w znacznym zakresie wyczerpują przesłanki zaistnienia fali demokratyzacji wyróżnione przez S.P. Huntingtona. Przyczyn wybuchu niezadowolenia społecznego poszukiwać można w słabej kondycji gospodarczej poszczególnych państw, korupcji, zawłaszczeniu państwa przez elity władzy, dysproporcjach rozwoju gospodarczego poszczególnych regionów. Niewątpliwie miał miejsce

${ }^{1}$ Wśród badaczy tzw. falowości cyklów demokratyzacji toczą się dyskusje, czy demokratyzacja państw Europy Środkowo-Wschodniej to jeszcze trzecia, czy czwarta fala. Większość z nich (L. Diamond, Ch. Kurzman) w odróżnieniu od S. Huntingtona przemiany w Europie Środkowo-Wschodniej lat 90. oraz tzw. kolorowe rewolucje w państwach postsowieckich zaliczają do czwartej fali demokratyzacji. To, co odróżnia Huntingtona od innych, wtórnych wobec niego autorów, to fakt pozostawienia interwału roku 1990 otwartego, co by oznaczało, że trzecia fala demokratyzacji jest kontynuowana do chwili obecnej, tak długo, jak nie będzie fali opozycyjnej. 
również tzw. efekt lawiny - wydarzenia w jednym państwie - Tunezji, w ciągu zaledwie dwóch miesięcy: styczeń-luty 2011, rozlały się na inne państwa bliższego i dalszego sąsiedztwa. Zdarzenia nie zachodziły jednakże równolegle i nie przyjęły ciągu zdarzeń, który pociągnął upadek reżimów w pozostałych państwach. Efekt domina nie zadziałał w Maroku, Bahrajnie, w przypadku Libii, Jemenu i Syrii kontestacja reżimu doprowadziła do wybuchu wojny domowej. Tym samym kolejna przesłanka fali demokratyzacji: liberalizacja systemu jako powszechnie uznane panaceum, nie zaistniała. Innymi słowy, teoria falowości, w której podobne czynniki wyjściowe powinny powodować podobne przeobrażenia - demokratyzację, w przypadku arabskiej wiosny się nie sprawdziła.

Szersze pole zastosowania w analizie procesów politycznych w Tunezji ma teoria dwuetapowości przemian, pojawiająca się w opracowaniach O’Donella, Schmittera, i Whiteheada.

Pierwszy z etapów przemiany ustrojowej w Tunezji - okres tranzycji, został zapoczątkowany wraz z ucieczką prezydenta Zine al Abidine ben Alego z kraju, tj. 14 stycznia 2011 r. Cezurę końcową pierwszego etapu przejścia demokratycznego i tym samym rozpoczęcie etapu konsolidacji demokracji wyznaczył przede wszystkim fakt przyjęcia konstytucji republiki Tunezji: 26 stycznia 2014 r. Data ta jest nie tylko symbolem inaugurującym drugą republikę, ale również przypieczętowaniem ustrojowych zasad, praw i wolności obywatelskich - reguł i norm, których trwanie i przestrzeganie znaczyć będzie o poziomie konsolidacji przemian zapoczątkowanych w 2011 r. Przeprowadzone w tym samym roku pierwsze, wolne wybory parlamentarne w historii niepodległej Tunezji (26 października 2011 r.), następnie prezydenckie w dniu 23 listopada tegoż roku, przypieczętowały fakt wyboru demokratycznej ścieżki rozwoju.

Przyglądając się pierwszemu elementowi przejścia demokratycznego - etapowi tranzycji, można wyróżnić w nim dwie odrębne fazy. Pierwsza (14 stycznia-15 marzec 2011 r.) naznaczona była próbą "przechwycenia rewolucji” przez przedstawicieli wcześniejszego systemu, tj. współpracowników Ben Alego i członków partii prezydenckiej RCD (Zgromadzenie Konstytucyjno-Demokratyczne). Druga faza pierwszego etapu tranzycji rozpoczęła się wraz z powołaniem instytucji okresu przejściowego, posiadającej legitymizację rewolucyjną, w dniu 15 marca $2011 \mathrm{r}$.

Warto zauważyć, że w następstwie opuszczenia kraju przez Ben Alego zastosowanie znalazł artykuł 56 Konstytucji z 1959 r., zgodnie z którym w wyniku faktu czasowej niemożności wypełniania funkcji przez prezydenta republiki, rolę tę na czas wyłonienia nowej głowy państwa przejmuje premier (art. 56). Tym samym 
Tunezja uniknęła sytuacji tzw. okresu próżni politycznej. Mohamed Ghannouchi, premier rządu okresu Ben Alego, objął funkcję tymczasowego prezydenta do dnia następnego, tj. momentu, w którym funkcję tę zgodnie $\mathrm{z}$ zapisem artykułu 57 konstytucji objął przewodniczący Izby deputowanych: Fouad Mebazaa. W okresie 16 stycznia - 15 marca 2011 r. - tworzono kolejne rządy tzw. jedności narodowej, wszystkie kontestowane przez największe organizacje opozycyjne i głośno oprotestowane w ogólnonarodowych manifestacjach. Kontrowersje budził każdorazowo skład gremium egzekutywy okresu przejściowego, w którym zasiadali członkowie reżimu Ben Alego (Hachemaoui, 2013). Okres pierwszy po obaleniu reżimu autorytarnego nazywać można próbą „zagarnięcia rewolucji jaśminowej" przez członków byłego reżimu. Nasuwa się więc całkiem zasadne pytanie, czy okres ten należałoby już zaliczyć do fazy transformacji czy jeszcze do wcześniejszego etapu schyłkowego dawnego reżimu? Transformacja polityczna w Tunezji rozpoczyna się więc konfliktem z jednej strony elit politycznych, trzymających się władzy pod przykrywką przyjmującego różne konfiguracje rządu jedności narodowej a ugrupowaniami opozycji i przedstawicielami społeczeństwa obywatelskiego, którego w centrum pozostaje pytanie o legitymację do przewodzenia procesowi transformacji.

W dniu 15 marca 2011 r. dochodzi do powołania Wysokiej Instancji na rzecz Realizacji Celów Rewolucji, Reformy Politycznej i Tranzycji Demokratycznej, której reprezentanci posiadają legitymację rewolucyjną (Bras, Gobe, 2017). To za sprawą tej instytucji okresu przejściowego dojdzie do opracowania szeregu norm i dekretów prowadzących do wyborów do konstytuanty, a później wyborów parlamentarnych i prezydenckich.

Po wyborach parlamentarnych i prezydenckich 2014 r., stanowiących preludium do 2 Republiki, Tunezja zakończyła proces tranzycji i weszła w etap konsolidacji demokracji. Instytucje i normy przyjęte podczas okresu przejściowego (Konstytucja, Zgromadzenie, ciała doradcze) od tej pory rozpoczęły proces głębszego zakorzeniania w społeczno-politycznym krajobrazie Tunezji.

\section{MODEL PRZEJŚCIA DEMOKRATYCZNEGO}

W wspominanym bazowym dziele dla tranzytologii w obecnym paradygmacie, Transition from Authoritarian Rule, autorzy konkludują, że porozumienie między aktorami politycznymi w kwestii nowych zasad stanowi fundament powodzenia transformacji demokratycznej. Konsensus (arab: al tawâfuq), jako wynik wzajem- 
nych ustępstw, stał się kamieniem węgielnym pod budowę demokracji w Tunezji i wiodącym modelem w procesie jej utrwalania (Kerrou, 2013).

Pierwszym przypadkiem zastosowania metody konsensualnej w sytuacji rewolucyjnej Tunezji było ustanowienie Wysokiej Instancji na rzecz Ochrony Celów Rewolucji, Reformy Politycznej i Tranzycji Demokratycznej. Wart odnotowania pozostaje fakt, że organ ten powołany został przy zachowaniu ciągłości instytucjonalno-prawnej państwa. Dekret rządowy wydany w dniu 18 lutego 2011 r. przez trzeci rząd okresu przejściowego pod przewodnictwem Beji Caïda Essebsi był dowodem ugody z reprezentantami społeczeństwa obywatelskiego (Bras, Gobe, 2017). Instancja przejęła funkcje reprezentanta narodu o legitymizacji rewolucyjnej do czasu wyłonienia nowej egzekutywy. Gremium rozpoczęło swą działalność 15 marca 2011 r., zakończyło funkcję wraz z wypełnieniem roli - doprowadzeniem do wyborów do Zgromadzenia Konstytucyjnego 23 października tegoż roku.

Konsens jako modus operandi zaistniał nie tylko w momencie tworzenia, ale także doboru składu instytucji oraz procedur podejmowania decyzji. W Instancji zasiadali przedstawiciele dwunastu partii politycznych, osiemnastu związków zawodowych, przedstawiciele organizacji społecznych. Heterogeniczność składu przejawiała się w uczestnictwie przedstawicieli skrajnych względem siebie nurtów ideowych, od partii umiarkowanego islamu (Ennahda) po partie lewicowe. W marcu organ liczył 155 członków (Séréni, 2011). Konsens pojawił się w formie poszukiwania szerokiej bazy społecznej porozumienia, będącego wynikiem negocjacji z udziałem jak największej liczby organizacji społecznych i przy różnorodności aktorów zaangażowanych w proces podejmowania decyzji. W duchu metody konsensualnej utrzymano również procedury podejmowania decyzji. Zasady te znalazły odzwierciedlenie w artykule 5 dekretu z 18 lutego 2011, dotyczącego regulaminu Wysokiej Instancji ds. realizacji Celów Rewolucji, Reformy politycznej i Tranzycji Demokratycznej. Artykuł 5 dekretu z 18 lutego 2011 r., wskazywał konsens jako procedurę podejmowania decyzji (Bras, Gobe, 2017).

$\mathrm{W}$ drodze konsensu $\mathrm{w}$ tak heterogenicznym gronie wypracowano zasady ordynacji wyborczej do Konstytuanty i powołano organ odpowiedzialny za organizację wyborów - Wysoką Instancję ds. Wyborów (18 kwietnia 2011 r.). Wybór członków tej ostatniej nie uniknął spięcia między członkami Instancji na Rzecz ochrony Rewolucji. Impas doprowadził do opuszczenia organów przejściowych przez przedstawicieli ugrupowania Ennahda, nie zniweczył zaś samego meritum porozumienia - przyjęcia ordynacji wyborczej i przeprowadzenia wyborów do Zgromadzenia Konstytucyjnego (Chamsi, 2017). 
Wybory z dnia 23 października 2011 r. przyniosły zwycięstwo partii Ennahda, która zdobyła 89 na 217 miejsc w Zgromadzeniu Konstytucyjnym. Partia weszła w koalicję z dwoma partiami sekularystycznymi - Ettakatol oraz Kongres na rzecz Republiki, co pozwoliło uzyskać większość w zgromadzeniu i utworzyć rząd.

Rząd tzw. Troïki, jako że skupił partie bardzo oddalone od siebie ideologicznie, nie był w stanie przeprowadzić reform gospodarczych i politycznych na skalę potrzeb i oczekiwań społecznych. Co więcej, przedstawiciele ugrupowań rządzących, podkreślając, iż posiadają legitymację wyborczą i - co za tym idzie - demokratyczną, często określali siebie jako jedyni reprezentanci społeczeństwa, deprecjonując znaczenie i możliwość podejmowania debaty politycznej przez reprezentantów opozycji (Chamsi, 2017).

W czerwcu 2012 r. na scenie politycznej Tunezji pojawiła się nowa opozycyjna partia polityczna Nidâa Tounes, utworzona przez aktualnego prezydenta Tunezji Béji Caïd Essebsi. Polityk łączony z obozem politycznym, bliskim ideom pierwszego prezydenta niepodległej Tunezji - Habiby Bourguiby - nawoływał do konieczności powrotu do konsensu jako reguły gry politycznej. Propozycje Essebsiego spotkały się z pozytywnym odzewem społecznym. Projekt Nidâa Tounes miał być odpowiedzią na złą sytuację społeczno-polityczną państwa.

Inercja kolejnych rządów Ennahdy, niezdolność gwarancji bezpieczeństwa wobec wzrastającego zagrożenia terroryzmem (ataki w Sous, Tunisie, górach Chambi w latach 2012-2013) oraz brak wyczekiwanych reform, mających stanowić remedium na bezrobocie, brak i wzrost cen, potęgowały niezadowolenie społeczne. Kryzys polityczny, wywołany zabójstwami politycznymi dwóch działaczy lewicy, Chokri Belaïda oraz Mohameda Brahmi, za którymi stali salfici łączeni z Ennahda, przelał przysłowiową „czarę goryczy”. Przez państwo przetoczyła się fala protestów społecznych. Nad Tunezją zawisła groźba kolejnej rewolucji. Kontekst polityczny, ale też pragmatyzm przewodniczącego partii Ennahda - Rachida Ghanouchiego - doprowadził do historycznego porozumienia - konsensu - w okresie transformacji Tunezji. W lipcu 2013 r. doszło do uformowania się platformy konsultacyjnej, w której obok strony rządzącej uczestniczył tzw. Kwartet na rzecz dialogu narodowego, w skład którego weszły cztery organizacje: Generalna Unia Pracowników Tunezyjskich, Unia Tunezyjska ds. Przemysłu, Handlu i Rzemiosła, Izba Narodowa Adwokatów Tunezyjskich, Tunezyjska Liga Praw Człowieka². Celem powołanego gremium było wypraco-

2 Kwartet na rzecz dialogu narodowego został w 2015 r. odznaczony pokojową nagrodą Nobla w uznaniu za wysiłki w budowie demokratycznego państwa. 
wanie mapy drogowej działań politycznych, służących zapobieżeniu kryzysu. Konsultacje doprowadziły rząd Troïki do zmiany strategii politycznej opierającej się konfrontacji w kierunku postawy dialogicznej. W wyniku porozumienia doszło do rozwiązania egzekutywy i powołania w grudniu 2013 r. rządu tzw. technokratów pod wodzą Mehdiego Jomaa, którego zadaniem było zarządzanie sprawami bieżącymi, a przede wszystkim doprowadzenie do wyborów parlamentarnych i prezydenckich przed końcem 2014 r. oraz przyjęcie nowej konstytucji (Bel Aïba, 2013).

Wolta polityczna nie wynikała tylko i wyłącznie z gotowości Troïki pod wodzą partii islamistów do powrotu do rozwiązań politycznych w drodze dialogu, a tym samym porzucenia legitymizacji wyborczej i demokratycznej do rządzenia. Optując za rozwiązaniem konsensualnym i de facto oddając władzę wynikającą z legitymacji demokratycznej - wyborów, Ghanouchi przekonywał o konieczności utrzymania spójności i pokoju społecznego, przerzucając tym samym część odpowiedzialności na rząd wyłoniony w drodze konsultacji.

Te same argumenty - imperatyw gwarancji pokoju społecznego - przyświecały opracowaniu nowej konstytucji, będącej rezultatem kompromisu między deputowanymi parlamentu - Ennahdy i koalicjantów z przedstawicielami społeczeństwa obywatelskiego. Przyjęcie konstytucji dnia 26 stycznia 2014 r., ustanawiającej drugą republikę, zostało poprzedzone manifestacjami ulicznymi przeciwników religijnej - islamskiej wizji państwa, promowanej przez obóz rządzących. Po blisko roku ostrych sporów toczonych przede wszystkim w zgromadzeniu, ale również w mediach, partia u władzy po raz kolejny odwołała się do kompromisu jako zasady rozstrzygnięcia sporu wokół tekstu konstytucji. W pierwszych dniach stycznia 2014 r. powołana została Komisja na rzecz konsensu (arab. lejnat el tawafukat), której celem było wypracowanie ostatecznego tekstu ustawy zasadniczej i znalezienie modus vivendi w kwestiach różniących zwolenników sekularystycznej oraz islamskiej wizji państwa, dotyczących przede wszystkim określenia relacji między religią a państwem i statusu kobiet w społeczeństwie Tunezji (Chouikha, 2014).

O tym, że jest to tekst konsensualny, świadczą przyjęte sformułowania. Artykuł 1 . Konstytucji został powtórzony w tym samym brzmieniu co w konstytucji z 1959 r.: „Tunezja jest wolnym państwem, niezależnym i suwerennym, islam jest jego religią (...), arabski językiem, o ustroju republikańskim”. Artykuł stał się przedmiotem sporu ideologicznego między modernistyczną wizji państwa i islamistami. Zapis, niewskazujący islamu jako źródła prawa, ale nieoddzielający też jednoznacznie państwa od religii, pozostawał niejasny i mógł podlegać 
swobodzie interpretacyjnej w zależności od intencji interpretującego, w domyśle rządzącego ${ }^{3}$.

Aby usunąć dwuznaczność semantyczną, zgromadzenie przyjęło artykuł 2, który stanowi, że „Tunezja jest państwem świeckim, opartym na obywatelstwie, woli ludu, prymacie prawa”. Użyte sformułowanie, państwo świeckie, w wersji francuskiej tekstu (état civil, fr.), zgodnie z kompromisem wypracowanym w komisji, gwarantuje nie tyle neutralność światopoglądową państwa, co charakter pozytywny stanowionego prawa (Tamzini, 2015). Tym samym zwolennicy wizji sekularystycznej państwa uniknęli wpisania szariatu jako źródła prawa, a Ennahda zapisu o stricte laickim charakterze państwa ${ }^{4}$.

Przedmiotem sporu doktrynalnego stał się również artykuł 21 konstytucji, gwarantujący równość obywateli i obywatelek Tunezji. Po długotrwałych debatach i przy nacisku ze strony organizacji społeczeństwa obywatelskiego udało się usunąć $\mathrm{z}$ projektu zapis o gwarancji równości płci, ale w ramach zgodnej z szariatem zasady „komplementarności ról męskich i żeńskich”, co de facto oznaczałoby niższy status kobiety.

Choć konsensus stał się centralnym punktem uzgadniania tekstu konstytucyjnego, nie oznacza to, że ustawa zasadnicza jest wolna od wad i dwuznaczności. Kontrowersje pojawiają się przy ustaleniu relacji dwóch ośrodków władzy wykonawczej: prezydenta i szefa rządu. Druga ambiwalencja nasuwa się przy ustaleniu hierarchii źródeł prawa. Nieścisłość pojawia się choćby w uznaniu wartości uniwersalnych praw człowieka, potwierdzonych w standardach międzynarodowych z jednej strony, i odniesień do nauk islamu i wartości arabsko-muzułmańskich $\mathrm{z}$ drugiej.

Bez względu na braki i niedociągnięcia ustawy zasadniczej niezaprzeczalny pozostaje fakt, iż jej kompromisowy charakter pozwolił na przyjęcie konstytucji przytłaczającą większością głosów (200 deputowanych „za”, 12 „przeciw” i 4 „wstrzymujących się") i przyczynił się do odblokowania patowej sytuacji politycznej w Tunezji u schyłku 2014 r.

3 Z jednej strony można odczytywać go explicite jako wskazanie, iż islam jest religią państwową, z drugiej zwolennicy świeckiej formy państwa mogą przypisywać mu charakter czysto opisowy, stwierdzający fakt rzeczywistości społecznej, w której islam jest religią większości Tunezyjczyków.

${ }^{4}$ Relacje państwa i islamu są gwarantowane nie tylko na podstawie kontrowersyjnego, jak już zostało wspomniane powyżej, artykułu pierwszego, ale także szóstego, który reguluje prawa i wolności obywatelskie. W jego brzmieniu: "Państwo jest strażnikiem religii, gwarantuje wolność wyznania, wykonywania kultu, jest gwarantem neutralności meczetów i miejsc świętych, chroni przed ich potencjalną instrumentalizacją. (...) chroni sacrum, przed próbami znieważenia...." 


\section{PODSUMOWANIE}

Wśród państw regionu Tunezja figuruje jako wyjątek. Pomimo nadziei na transformację bliskowschodnich reżimów autorytarnych, którą niosła ze sobą arabska wiosna, demokracja nie stała się wiodącym modelem zmiany politycznej. W Egipcie doszło do restauracji reżimu autorytarnego, Jemen i Syria pogrążyły się w wojnie domowej. Niemal wszystkie państwa, które doświadczyły rewolucyjnego zrywu, rozpoczętego w Tunezji w 2011 r., borykają się ze zjawiskami dżihadyzmu, konfliktów klanowych i wyznaniowych.

Tunezja pomimo licznych nieprzewidywalnych zwrotów akcji i trudności tzw. okresu przejściowego, naznaczonego choćby zabójstwami politycznymi, krwawo tłumionymi manifestacjami, podminowywaniem porządku społecznego aktywnością terrorystów islamskich, zdołała zachować republikańskie instytucje, opracować i przyjąć nową konstytucję, przeprowadzić z powodzeniem dwie tury wyborów parlamentarnych i prezydenckich. Udany, jak do tej pory, przebieg procesu demokratyzacji w Tunezji jest wynikiem wielu zmiennych. Oprócz odmiennego i zgoła bardziej sprzyjającego gruntu natury społeczno-demograficznej (brak podziałów religijnych i etnicznych społeczeństwa tunezyjskiego), dotychczasowe sukcesy przypisać można koncyliacyjnej postawie głównych aktorów politycznych i obranemu modelowi zmiany - konsensowi.

Pomimo pozytywnego obrazu, jaki wyłania się z analizy dotychczasowych wydarzeń politycznych, nie może umknąć uwadze fakt, że za obraną strategią działań kluczowych aktorów zmiany systemowej, w tym Ennahdy, stoi kalkulacja polityczna i przygotowywanie korzystnego gruntu pod kolejne wybory. Nie wszystkie konsensualne ustalenia, choćby tekstu konstytucji, są wolne od dwuznaczności. Co więcej, konsens na poziomie instytucjonalnym nie stanowi o sile konsensu na poziomie społecznym. O ile rozbieżności, w głównej mierze ideologiczne, udało się załagodzić na poziomie elit politycznych, o tyle rywalizacja między laickim i konserwatywnym modelem państwa wciąż występuje wśród społeczeństwa. Na braku społecznej legitymizacji działań politycznych może zaważyć utrzymująca się trudna sytuacja gospodarcza państwa, brak poprawy warunków życia, wysokie bezrobocie, nierówności społeczne, przesłanki, które doprowadziły do rewolucji w $2011 \mathrm{r}$. Gorzkim testem poparcia społecznego dla elit politycznych były pierwsze przeprowadzone po rewolucji $2011 \mathrm{r}$. wybory samorządowe w dniu 6 maja 2018 r. Pierwsza lekcja, jaka z nich wypływa, to niska frekwencja wyborcza, rzędu 33\%, którą można interpretować jako ogólne zwątpienie w demokratyczną drogę państwa i przypisywać złej komunikacji 
na linii elity-społeczeństwo (Dahmani, 2018). Co więcej, słabe w stosunku do wyborów parlamentarnych z 2014 r., poparcie dla dwóch dominujących partii rządzących, zwłaszcza Nidâa Tounes (Nidâa Tounes - 22,5\%, Ennahda - 27,5\%) może być odczytywane jako votum nieufności wobec prowadzonej przez nie polityki (Dahmani, 2018). O tym, czy proces demokratyzacji w Tunezji będzie kontynuowany, przesądzi gotowość wchodzenia w koalicje i współrządzenie w radach miejskich. Efektywna koabitacja dwóch wyżej wymienionych partii, ale i innych ugrupowań i radnych „niezależnych” będzie probierzem kontynuacji modelu konsensualnego w procesie demokratyzacji Tunezji.

\section{BiBLIOGRAFIA:}

Antoszewski, A. (2011). Demokratyzacja w Polsce w świetle współczesnej tranzytologii. Working paper 1/2011, Uniwersytet Wrocławski. Pobrane z: http://politologia.uni. wroc.pl/zspa/images/stories/dylematy\%20tranzytologii.pdf.

Bel Aïba, I. (2013). Dialogue national: La majorité des acteurs de la classe politique tunisienne signe la feuille de route. HuffPostb Maghreb. Pobrane z: https://www. huffpostmaghreb.com/2013/10/05/signature-feuille-de-route-tunisie_n_4049931. html?utm_hp_ref=maghreb.

Ben Hamadi, M. (2013). Crise politique en Tunisie: Ennahdha n’a jamais accepté la feuille de route du quartet. HuffPost Maghreb. Pobrane z: https://www.huffpostmaghreb.com/2013/10/07/tunisie-ennahdha_n_4055767.html.

Ben Néfissa, S. (2012). Trajectoires transitionnelles et élections en Tunisie et en Égypte. Confluences Méditerranée, $n r$ 8, 2012/3, s. 9-27, l'Harmattan.

Bonnefoy, L. (2011). Les révolutionssont-ellesexportables? "L'effet domino" à la lumière du cas yéménite. Mouvements, 66, 110-116.

Bozonnet, Ch. (2017). Tunisie: La démocratie est un processus difficile, mais on ne reviendra jamais à la dictature. Monde Afrique. Pobrane z: http://www.lemonde. fr/afrique/article/2017/11/17/tunisie-la-democratie-est-un-processus-difficilemais-on-ne-reviendra-jamais-a-la-dictature_5216500_3212.html\#MrHS5iuGCsrT0uod.99.

Bras, J-P., Gobe, E. (2017). Légitimité et révolution en Tunisie. Revue des mondes musulmans et de la Méditerranée, nr 142. Pobrane z: http://journals.openedition. org/remmm/9573.

Burton, M., Highley, J. (1987). Elite Settlements. American Sociological Review, 52, 295-307.

5 W wyborach parlamentarnych 2014 r., partia Nidâa Tounes uzyskała poparcie rzędu 37, 6\%, Ennahda 27,6\%). 
Chamzi, M.Z. (2017). Tunisie - Consensus sur la scène politique. The Maghreb and Orient Curier, 39. Pobrane z: https://lecourrierdumaghrebetdelorient.info/focus/ tunisie-consensus-sur-la-scene-politique/.

Chouikha, L. (2016). Ennahada - de la polarization au consensus: Les tentations hégémoniques du mouvement islamiste semblent s'estomper au profit d'une'démarche consensuelle': pragmatisme ou tactique? IEMed: European Institute of the Mediterranean. Pobrane z: http://www.iemed.org/observatori/arees-danalisi/arxius-adjunts/afkar/ afkar-ideas-41/Ennahdha-\%20de\%20la\%20polarisation\%20au\%20consensus\%20 -Larbi\%20Chouikha.pdf.

Dahmani, F. (2018). Tunisie: seulement 33,7\% de participation pour les premières municipales de l'après-révolution. Jeune Afrique. Pobrane z: http://www.jeuneafrique.com/557942/politique/tunisie-seulement-337-de-participation-pour-lespremieres-municipales-de-lapres-revolution/.

Diamond, L., (1997). Is the Third Wave of Democratization Over? Empirical Assessment. Working Paper 236. Pobrane z: http://citeseerx.ist.psu.edu/viewdoc/download?doi=10.1.1.122.4030\&rep=rep1\&type $=$ pdf.

Dunay, A.M. (2017). The Fourth Wave of Democratization: A Comparative Analysis of Tunisia and Egypt. Pobrane z: http://commons.lib.jmu.edu/honors201019/344.

El Husseini, F. (2016). Printemps arabe: théorie du complot ou élan populaire? Contreligne. Pobrane z: http://www.contreligne.eu/2013/06/le-printemps-arabe-theoriedu-complot-ou-elan-populaire/.

Guilhot, N., Schmitter, P.C. (2000). De la transition à la consolidation. Une lecture rétrospective des democratizationstudies. Revue française de science politique, 50(4-5), 615-632.

Hachemaoui, M. (2013). La Tunisie à la croisée des Chemins. Quelles règles pour quelle transition? SWP Research Paper. Pobrane z: https://www.swp-berlin.org/fileadmin/ contents/products/research_papers/2013_RP06f_hmu.pdf.

Huntington, S.P. (1995). Trzecia fala demokratyzacji. Warszawa: PWN. Kerrou, M. (2016). Challenges and Stakes of State and Societal Resilience in Tunisia. IAI Working Paper 2017, Instituto Affari Internazionali, nr 31. Pobrane z: http://www. iai.it/en/pubblicazioni/challenges-and-stakes-state-and-societal-resilience-tunisia.

Konstytucja Republiki Tunezyjskiej. (2015). Dziennik urzędowy, 20 kwietnia 2015. Pobrane z: http://www.legislation.tn/sites/default/files/news/constitution-b-a-t.pdf.

Kurzman, Ch. (1998). Waves of Democratization. Studies in Comparative International Development, 33(1), 42-64.

Markoff, J. (2015). Waves of Democracy: Social Movements and Political Change. Londyn: Routledge.

Nachi, M. (2016). Transition to Democracy in Tunisia: Learning About Citizenship in a National and Transnational Context. Social Science Information, 55(4), 429-445. Pobrane z: https://doi.org/10.1177/0539018416658151.

O'Donnell, G., Schmitter, P., Whitehead, L. (red). (1986). Transitions from Authoritarian Rule. Prospects for Democracy, t. 1-4. Baltimore: The John Hopkins University Press. 
Potocki, R., Piskorski, M., Hładkiewicz, W. (2014). Fale Tunisami. Warszawa: Wydawnictwo: Europejskie Centrum Analiz Geopolitycznych.

Przeworski, A. (1986). Some Problems in the Study of Democratic Transitions. W: G. O 'Donnel, P. Schmitter, L. Whitehead (red.). Transitions from Authoritarian Rule: Prospects for Democracy, s. 121-145. Baltimore: John Hopkins University Press.

Rustow, D. (1970). Transitions to Democracy. Toward a Dynamic Model. Comparative Politics, 3, 337-363.

Schedler, A. (1997a). Concepts of Democratic Consolidation. Paper delivered at the 1997 Meeting of the Latin American Studies Association LASA, Guadalajara Mexico 17-19 April 1997. Pobrane z: http://lasa.international.pitt.edu/LASA97/schedler. pdf.

Schedler, A. (1997b). Expected Stability Defining and Measuring Democratic Consolidation. Institute for Advanced Studies, Vienna. Pobrane z: http://irihs.ihs.ac.at/1026/1/ pw_50.pdf.

Séréni, J.P. (2011). En Tunisie, les soubresauts de la révolution. Le Monde diplomatique, 686,4 .

Shared, D. (1987). Transition to Democracy and Transition Through Transaction. Comparative Political Studies, 19, 5, 525-548.

Tamzini, W. (2015). La nouvelle constitution tunisienne du 26 janvier 2014-entre tradition et modernité. Centre International pour la Paix et les Droit de l'Homme, 20 maja 2015. Pobrane z: http://www.cipadh.org/fr/la-nouvelle-constitution-tunisienne-du26-janvier-2014-entre-tradition-et-modernit\%C3\%A9.

Yahya, M. (2016). Great Expectations in Tunisia. Carnegie Middle East Penter, Paper, 31 marca 2016. Pobrane z: http://carnegie-mec.org/2016/03/31/great-expectations-in-tunisia-pub-63138. 